\title{
Computational System for Sizing Wind Energy Generation Systems Using Artificial Neural Networks
}

\author{
Rafael Gil Ferques ${ }^{1,2}$, C. E. C. Nogueira ${ }^{1}$, A. M. Meneghetti ${ }^{3}$ \& D. M. Rocha ${ }^{3}$ \\ ${ }^{1}$ Post-Graduation Program of Energy Engineering in Agriculture, State University of Western Paraná, Cascavel, \\ PR, Brazil \\ ${ }^{2}$ Federal Institute of Paraná, Quedas do Iguaçu, PR, Brazil \\ ${ }^{3}$ Federal Technological University of Paraná, Santa Helena, PR, Brazil \\ Correspondence: Rafael Gil Ferques, State University of Western Paraná, Cascavel, PR, Brazil. Tel: \\ 55-45-999-940-051. E-mail: rafael.ferques@ifpr.edu.br
}

$\begin{array}{lcc}\text { Received: July 4, } 2018 & \text { Accepted: August 4, } 2018 & \text { Online Published: September 15, } 2018 \\ \text { doi:10.5539/jas.v10n10p423 } & \text { URL: https://doi.org/10.5539/jas.v10n10p423 }\end{array}$

\begin{abstract}
The objective of this work was to develop a computational application for the design of wind power generation systems in small-scale On-Grid and Off-Grid installations, using a user friendly and interactive process. Using artificial intelligence concepts in conjunction with genetic algorithms, to verify the technical and economic viability of the implementation of the wind power generation system. The application coding was done using the languages Java, C, C++ and the database in MySQL language, containing technical specifications and costs of components of a wind system (of this type of system). For the development of neural networks and genetic algorithms, the Encog library was used. The application has proven effective in designing and economic analysis of small wind systems, allowing fast and simple simulation of On-Grid systems and Off-Grid systems. In addition, it proved effective in storing and accessing the information regarding the simulations performed and in the comparison between them, in order to perform a new simulation. Also, it was reliable in the accomplishment of the economic analysis, returning in a clear form the feasibility or not of the implantation of the project.
\end{abstract}

Keywords: genetic algorithms, energy, renewable energy, free software

\section{Introduction}

Wind energy is basically the kinetic energy (movement) generated by air masses caused by the temperature differences on the planet's surface, which rotates a set of propellers connected to an electricity generator. In Lopes (2011), the amount of energy produced is directly proportional to the size of its propellers, and to the local wind regime.

It has been applied since antiquity, but without a precise period, since it was used in the movement of boats in economic activity, in water pumping and grain milling, and is currently the most important application of this medium (ANEEL, 2008). The application of wind energy for electricity generation began in Denmark in 1980, in small agricultural equipment companies with own manufacturing, with generation capacity between 30 to $55 \mathrm{~kW}$ (Martins, Guarnieri, \& Pereira, 2008).

The installed capacity of wind power in the world in 1990 was less than 2,000 MW, in 1994 of 3,734 MW, divided between Europe (45.1\%), America (48.4\%), Asia (6.4\%) and other countries (1.1\%). In 1998 it reached $10,000 \mathrm{MW}$, and by the end of 2002 it surpassed 32,000 MW of capacity (Martins, Guarnieri, \& Pereira, 2008). Installed world capacity for wind power increased 1155\% between 1997 and 2007, from 7,500 to 93,800 MW (WWEA (Note 1)). The total global installed capacity of wind turbines for the production of electricity reached $74223 \mathrm{MW}$ at the end of 2006 , with growth of more than $20 \%$ compared to 2005 . In 2005 , only 55 countries adopted some type of incentive to renewable sources, this number jumped to 118 countries in 2011 (REN21, 2016). In that same year the wind capacity in operation in the world reached $238 \mathrm{GW}$ (GWEC, 2015).

The European Wind Energy Association set targets, and indicated that by 2020, wind power could supply $10 \%$ of all electricity in the world. In terms of installed capacity, it is estimated that by 2020 Europe will have 100,000 MW (Martins, Guarnieri, \& Pereira, 2008). China, Germany, the USA, Brazil, India, Canada, the United 
Kingdom, France and Turkey were the countries that increased the most installed wind power capacity in 2014 (GWEC, 2015).

Currently, $141.6 \mathrm{GW}$ are installed in the European Union, with a cumulative total capacity of $147.8 \mathrm{GW}$ for the whole of Europe. Wind energy accounts for $44.2 \%$ of all energy installation capacity, exceeding hydroelectric dams as the third largest source of energy in the European Union, accounting for $15.6 \%$ of total energy capacity by the end of 2015 (GWEC, 2015).

In Brazil, there were 92 wind farms authorized by ANEEL in 2003, and its growth has been constant in recent years. In 2013, $4.7 \mathrm{GW}$ of wind projects were contracted, and in 2014, $2.3 \mathrm{GW}$ - all to be deployed by 2019, when Brazilian wind capacity is expected to reach $15.2 \mathrm{GW}$. This capacity increased by around $60 \%$ in 2015 , from $6 \mathrm{GW}$ to $9.8 \mathrm{GW}$ (Abeeólica, 2016), representing $4.21 \%$ of installed capacity in the country and $5.54 \%$ of the national energy matrix, of which $73.08 \%$ are located in the northeast, and second is the southern region (ANEEL, 2015). In 2016, construction capacity in Brazil is $8.62 \mathrm{GW}$, representing $\mathrm{CO}_{2}$ reduction of $16,864,332$ T year-1, with 390 plants installed and installation capacity of $9.8 \mathrm{GW}$ (Abeeólica, 2016). According to Lopes (2011), Brazil has one of the largest wind potential on the planet, although wind is responsible for $0.03 \%$ of 92 thousand MW installed in the country.

According to the EIA - International Energy Agency in European countries and Asia, there has been growth of renewable energy, especially wind power. The increase in wind power generation in 2015 was equal to almost half of global growth of electric energy. This was made possible by factors such as industrial restructuring, improved energy efficiency and the growth of renewable energy such as wind power (GWEC, 2015).

According to ANEEL (2016), Brazil is among the countries with the highest percentage of wind energy in its energy matrix. This representation consists of about $6.15 \%$ of the total matrix. There is an estimated increase in the use of wind energy, from 1,700 MW in 2016 to 5,959 MW in 2018, and the states of the Brazilian Northeast are more representative in this generation, as detailed in Table 1.

Table 1. Participation of states in the production of wind energy (ANEEL, 2016)

\begin{tabular}{lll}
\hline State & Power in MW & Number of Plants \\
\hline Bahia & 5135.8 & 223 \\
Rio Grande do Norte & 4873.5 & 181 \\
Ceará & 2508.3 & 104 \\
Rio Grande do Sul & 2092.6 & 94 \\
Piauí & 1887.5 & 68 \\
Pernambuco & 878.6 & 38 \\
Maranhão & 264.3 & 10 \\
Santa Catarina & 241.5 & 16 \\
Paraíba & 159.0 & 16 \\
Sergipe & 34.5 & 1 \\
Rio de Janeiro & 28.0 & 1 \\
Paraná & 2.5 & 1 \\
Minas Gerais & 1.56 & 1 \\
São Paulo & 0.22 & 1 \\
\hline
\end{tabular}

Renewable energy technologies are capital intensive because most of the investment is concentrated in the initial phase of the project, corresponding to $75 \%$ of the total wind farm investment (Tourkolias \& Mirasgedis, 2011). Socioeconomic characteristics of many regions, such as unemployment, lack of economic development alternatives and high migration rates of the active population, make the investment in these technologies advantageous. In Nguyen (2007), due to these characteristics, the construction of power plants demands labour, generating potential for the training and employment of rural populations in several localities.

In 2004, the Federal Government created as bases for the model of the Brazilian energy sector, based on Laws 10,847 and 10,848, dated March 15, 2004 and Decree 5,163, dated July 30, 2004 (Melo, Santos, \& Yamamoto, 2016).

Considering that there are several regions with great potential for wind power generation in Brazil, and to ensure the growth of this energy source, the development of new technologies and investments are essential, and it is of 
great interest to create means to facilitate the deployment of significantly to achieve maximum efficiency in the use and transfer of energy from the wind. Having it in mind, the process sizing a wind power system is of great interest for projects where, in addition to the search for cost reduction in energy acquisition, there is a concern for greater efficiency in energy transformation.

To this end, two commercial energy markets were created as components of the new electric sector model, a regulated contracting environment (ACR), in which a set of distributors purchase electricity from generators in public auctions, with defined prices; and a free contracting environment (ACL), in which consumers and electricity producers freely negotiate their bilateral contracts. This official electric power market, operating through public auctions with long-term contracts (15 and 30 years), is an important instrument for consolidating the process of liberalization of the energy supply industry in Brazil, reducing investor risks, and stimulating efficiency with correct signs of the system's cost of expansion through competition, fuelled by studies of government-made planning (Abeeólica, 2016).

The ACL includes free market consumers who are entitled to choose their energy supplier by paying a fee for the use of the distribution or transmission system, with bilateral contracts and definitions of price, quantity, duration and coverage clauses. This market was created in Brazil for more than ten years. The right to be a free consumer was specified in Law 9,074/1995, amended by Law 9,648/1998 and complemented by ANEEL Resolution $264 / 1998$ and it was determined by this law that the market should be gradually liberated so that large consumers could become free.

The electricity system is responsible for the distribution of energy, whose operation is coordinated by the National System Operator (ONS), thus considering contracts in Brazil as financial instruments (Melo, Santos, \& Yamamoto, 2016).

The differences between production and consumption and the quantity contracted are settled in the spot market, defined according to the local price called the Settlement Price of Differences (PLD). The cash market transaction and the financial settlement process are the responsibility of the Electric Energy Trading Chamber.

The goal of this study was to develop a multiplatform computing system using artificial neural networks under the terms of the GNU General Public License (Note 2) for small-scale Off-Grid and On-Grid wind power systems, as well as to quantify wind turbines and the other components of the system, using an integrated database with the technical specifications and costs of the components of a wind system.

\section{Material and Methods}

\subsection{Software Development}

For the development of this study, the programming languages Java, C, C++ and MySQL database were used, which allowed a platform independence to execute the application, allowing it to run on any operating system. To manipulate these languages together, the Microsoft ${ }^{\circledR}$ Visual Studio 2015 Enterprise integrated development environment was used.

For the analysis of requirements and the development of this system, an object-oriented methodology was used with the modelling through the Unified Modelling Language (UML) and the fountain-type life cycle model (Sommerville, 2016; Pressman, 2014).

In relation to artificial neural networks and genetic algorithms, these were developed using Encog (Heaton, 2008), which is a Java programming library focused on the development of neural networks (Haykin, 2000).

All parts related to the Autorregressive and moving average models, were implemented using Matlab ${ }^{\circledR}$ software, using as a Toolbox System Identification (Ljung, 2016).

In order to integrate the Java and Matlab ${ }^{\circledR}$ development platforms, in order to organize the loading of files and analysis of the results, it was used the Matlabcontrol library (Note 3), which is a programming interface for controlling and interacting with Matlab ${ }^{\circledR}$ software sessions, from a Java application.

In order to facilitate the evaluation of the implemented models of artificial neural networks and genetic algorithms, several classes were constructed in languages $\mathrm{C}$ and Java for cost and sizing functions, in order to present the best scenario for this one.

\subsection{RNA Modelling}

In an RNA application project, it is necessary to specify several parameters and related factors in the network architecture such as the number of neurons in each layer, the number of hidden layers, the type of the activation 
function, the format of the input matrix of the data, such as data pre-processing information and learning algorithm.

In this study, the network that was used had multiple inputs and one output. The entries vary according to the specified template. It was also chosen by the multi-layer perception widely evaluated in other works Hamzaçebi (2008), Shamseldin (1997), Dawson (1998), Riad et al. (2004), Minnis (1996), with 3 layers, consisting of 1 input layer, 1 hidden layer and 1 output layer.

According to Gallant (1995), Thierens and Goldberg (1994), Sedki et al. (2009), Anders et al. (1999), Minns (1996) Wang et al. (2009) the results showed that more than one hidden layer does not play a decisive role in the generalization impact of the network, which may even increase the consumption of processing.

\subsection{Economic Aspects of Wind Energy Projects}

According to Dutra and Tolmasquim (2002), detailing the economic aspects of a project is as important as the analysis of technical feasibility and can be divided into two steps: initial project costs and annual costs for operation and maintenance. The initial costs of a wind project include charges such as: technical feasibility study, negotiations and development, engineering projects, equipment costs, infrastructure and miscellaneous expenses. For the annual costs of operation and maintenance, there are equipment costs (replacement and prevention), rental and use of the land, insurance, among others. The calculations for economic evaluation (cash flow, present value of money, economic indicators and sensitivity analysis) were done according (Luzio, 2014; Blasques, 2005; Melek, 2013). The calculations related to economic indicators (net present value (NPV), internal rate of return (IRR), and payback) and serve as a basis for comparative economic analysis in electric power generation projects were according to Newnan et al. (2013), Hoji, (2014), Rebellato (2004).

\subsection{Method of Designing Wind Power Systems}

To meet the objectives of the study, it is necessary to set a critical method, an end project or an oversized one. Another goal is to make this process simple to the user. According to Pinto (2013), the following stand out: wind data collection, energy demand to be met (for later delimitation of the number of wind generators and maximum current generated), quantity of load controllers and inverters, when necessary and quantification of the storage system for the Off-grid systems, with the number of batteries needed for a preference and a period of autonomy for which there is no power generation. Wind energy systems were also designed to detail the economic costs, such as costs, project initiatives and operating and maintenance costs.

The point that delimits the beginning of the sizing is the choice of the type of wind system, On-grid or Off-grid, which will influence the complexity of the project and the final cost. The next step is to obtain the wind data.

For this purpose, an access medium was created between the application and the information bank of the Brazilian Wind Potential Atlas of Cresesb (Note 4), which is a web platform that aims to provide information such as: average seasonal wind speed, predominant directions and Weibull statistical parameters, thematic maps and wind power flows for the whole country. This query was performed by inserting the geographical coordinates of the point of interest (Cresesb, 2014). If you prefer, you can manually enter the wind speed data collected to generate the average wind speed value and subsequent calculations.

Then, for the verification of the energy demand, the user had two conditions for defining the reference values and performing the calculations: i) Insertion of a value referring to average daily consumption, in $\mathrm{kWh}$ or; ii) Output of the simulator of average daily consumption, which allows the simulation of consumption based on the electrical equipment to be used, returning the average daily consumption in $\mathrm{kWh} / \mathrm{month}$.

With the definition of the type of wind system and possession of the values of the energy demand and average wind velocity, the wind energy design was started. It is extremely important to carry out simulations with several wind turbines of different powers and manufacturers, as well as with the other equipment, in order to verify the ones best suited to the characteristics of the region to which the power generation system is to be implemented, guaranteeing the minimization in the costs arising from this generation method. From that point on, the use of genetic algorithms was started, which aims to verify which will provide the best scenario for the implementation, making a comparison between all the equipment, analyzing all possible configurations with the equipment previously registered in the database of the platform, having as initial parameters of choice the lowest cost together with the least amount of equipment. Another purpose of the use of this algorithm is that, at the time of initialization of the simulation, it searches in its history whether or not there was similar simulation, thus minimizing the processing and optimizing the software performance. The calculations used to size were according to Pinho et al. (2008), Cresesb (2014), and Albano (2009). 


\subsubsection{Weibull Distribution}

Probability density records are important when described by analytical expressions, that is, the probability of the wind speed being equal to a given value. The distribution that best fits the wind parameters is called the Weibull distribution (Willis \& Scott, 2000).

The mathematical expression of the Weibull probability density function is:

$$
f(v)=\left(\frac{k}{c}\right)\left(\frac{v}{c}\right)^{k-1} e\left[-\left(\frac{v}{c}\right)\right]^{k}
$$

Where,

$\mathrm{k}=$ form factor (dimensionless); $\mathrm{c}=$ scale factor $(\mathrm{m} / \mathrm{s})$.

When little is known about the wind regime, a good starting point is to assume $k=2$; in this case the probability function is called the Rayleigh distribution, used for preliminary studies, when only the average wind speed is known to find its frequency of distribution (Pinto, 2013). For calculation of $c$ and $k$ of the Weibull parameters, we use:

$$
\begin{gathered}
c=\frac{\bar{v}}{\Gamma\left(1+\frac{1}{k}\right)} \\
\Gamma\left(1+\frac{1}{k}\right)=\int_{0}^{\infty} y^{\bar{k}} e(-y) \mathrm{d} y \\
k=\left(\frac{\sigma}{\bar{v}}\right)^{-1.086}, 1 \leq k \leq 10
\end{gathered}
$$

Where,

$\bar{v}=$ average wind speeds $(\mathrm{m} / \mathrm{s}) ; \sigma=$ standard deviation; $\Gamma=$ gamma function.

Wind speed varies on diurnal, monthly and annual scales. Most of the time the wind speed variation reaches $10 \%$ between its annual average value and the long term average, ie, the wind tends to a certain speed profile. For the analysis of wind speed data, such data are usually divided into $1 \mathrm{~m} / \mathrm{s}$ intervals, which are measured in anemometric stations, which record the wind speed in predefined bands in minutes or hours (Pinto, 2013). The probability density function of the wind speed can be calculated for each hour of the typical day in the month, using time series data.

\subsubsection{Correction Wind Speed According to Height}

For Jangamshetti; Rau (2009) the wind speed varies according to the height, since as the height increases, the wind speed also increases in magnitude. Thus, the relationship between velocities $v 1$ and $v 2$ at heights $h 1$ and $h 2$ can be approximated by the law of power:

$$
\frac{v_{2}}{v_{1}}=\left(\frac{h_{2}}{h_{1}}\right)^{\alpha}
$$

Where $\alpha$ is the (dimensionless) power exponent, estimated from the averages of the specific heights $h 1$ and $h 2$, through Equation 6:

$$
\alpha=\frac{\left[\ln \left(\frac{v_{2}}{v_{1}}\right)\right]}{\left[\ln \left(\frac{h_{2}}{h_{1}}\right)\right]}
$$

By obtaining a new wind speed from the previous expression, it is possible to delimit the wind speed according to the height of the wind turbine. Through the relation between wind speed and height, the following expression can be used to delimit the wind speed at a certain reference height:

Where,

$$
v_{3}=v_{2}\left(\frac{h_{3}}{h_{2}}\right)^{\alpha}
$$

$\mathrm{v}_{3}$ is the wind speed at height $\mathrm{h}_{3}, \mathrm{~m} / \mathrm{s} ; \mathrm{v}_{2}$ is the wind velocity at height $\mathrm{h}_{2}$, obtained by direct measurement, $\mathrm{m} / \mathrm{s}$;

$\alpha$ is a coefficient relative to the roughness of the soil surface in that region, usually determined by local experimental measurements. 


\subsubsection{Total Daily Load Capacity}

According to Pinho et al. (2008) the calculation of the energy produced by a wind turbine allows the evaluation of any project that aims to use wind energy for the generation of electricity. One way of estimating the electric energy produced by the measured wind data series using the wind speed frequency distribution over a period of time and applying this distribution to the output power curve of the wind turbine. The power curve of the wind turbines indicates the electrical output of the wind turbine to a load, a storage system, or a power grid, depending on the wind speed at the rotor height. The result of the application of the frequency distribution to the power curve of the wind turbines provides the amount of energy produced in the considered period.

Equation 8 relates the total daily load capacity to the specifications of the wind turbine, to later delimit the number of wind turbines required for the project.

$$
C C D T=\frac{\left(\frac{C I \times D D C A}{R I}\right)}{T N A}
$$

Where,

$\mathrm{CCDT}=$ total daily load capacity (Ah/day); $\mathrm{CI}=$ safety coefficient (dimensionless); DDAC = daily demand of energy in alternating current $(\mathrm{Wh} /$ day $)$; TNA $=$ Nominal voltage of wind turbine $(\mathrm{V}) ; \mathrm{RI}=$ Inverter Yield $(\%)$.

\subsubsection{Number of Wind Turbines}

Equation 9 calculates the number of wind turbines that will be needed to meet the daily demand of the project.

$$
N A=\frac{C C D T}{C D A V M}
$$

Where,

$\mathrm{NA}=$ number of wind turbines (un.); CCDT = daily capacity of total load (Ah/day); CDAVM = daily load of wind turbine, calculated as a function of the wind speed distribution and the power curve of the equipment (Ah/day).

\subsubsection{Maximum Wind Turbine Current}

Equation 10 calculates the maximum current produced by the wind turbines that will be necessary for the project.

$$
M C A=C A P N \times N A
$$

Where,

$\mathrm{MCA}=$ maximum current supplied by wind turbine (A); CAPN = wind turbine current at nominal power (A); $\mathrm{NA}=$ number of wind turbines (un.).

\subsubsection{Number of Load Controllers}

Load controllers have the function of controlling the flow of energy between the generator and the batteries, protecting them from being overloaded or discharged deeply, which will influence the increase in the life of the battery banks. The load controllers must be selected based on the voltage and current characteristics involved in the wind system (Ackermann, 2012).

With the current data of the equipment and the load controller, it was possible to determine the number of controllers, according to Equation 11.

$$
N C C=\frac{M C A}{C C C}
$$

Where,

$\mathrm{NCC}=$ number of load controllers (un.); MCA = maximum current supplied by wind turbine (A); CCC = load controller current (A).

\subsubsection{Battery Bank Capacity}

After obtaining the maximum current data and the load capacity it was possible to establish the capacity of the energy storage system. The goal is to ensure that, on days of wind shortage, the energy demand is met, and the maximum discharge level allowed for the battery (ies) is not exceeded.

The type of battery that is used was initially chosen taking into account the specifications of each manufacturer. After choosing it, the depth of discharge to be worked was defined. The deeper the charge and discharge cycles, 
the shorter the battery life. For this definition, the life-time curves shall be used according to the depth of the discharge provided by the manufacturers.

With the data of windless days, as well as other parameters of the battery, wind turbine and demand, it was possible to calculate the capacity of the battery bank, using Equation 12:

$$
C B B=\frac{C C D T \times D S V}{P D F A}
$$

Where,

$\mathrm{CBB}=$ storage capacity of battery bank, in $\mathrm{Ah} ; \mathrm{CCDT}=$ total daily charge capacity, in Ah/day; PDFA = discharge depth at end of range, decimal; DSV = autonomy-days without wind in the critical month, in days.

\subsubsection{Number of Batteries}

With Equation 13, it was possible to calculate the number of batteries needed to compose the storage system in order to support the energy demand of the project.

$$
N B=\frac{C B B}{C B}
$$

Where,

$\mathrm{NB}=$ number of batteries (un.); $\mathrm{CBB}=$ storage capacity of battery bank (Ah); $\mathrm{CB}=$ storage capacity of a battery (Ah).

\subsubsection{Number of Inverters}

Inverters have the main function of converting direct current and generated by the wind turbines in alternating current available to the grid, adjusting the frequency and the voltage level of the grid to be connected. In On-grid systems they also have the function of emitting information about the energy production and the interaction with the electric network (Ackermann, 2012).

The parameters necessary sizing the voltage inverter are: i) input and output voltages and; ii) nominal power of continuous use and of short duration. Also, it is necessary to check the total power of the alternating current loads and select an inverter with minimum safety capacity above the requirement (value to be delimited). The input voltage must be equal to the voltage of the batteries and the output equal to the voltage of the alternating current loads. If the summary of loads has resulted in the sum of the loads installed in alternating current is of $100 \mathrm{~W}$, the inverter must have a minimum capacity for continuous operation of the same proportion plus the safety value. Equation 14 calculates the amount of inverters that will be needed to service the system:

$$
N I=\frac{D M P}{P I}
$$

Where,

$\mathrm{NI}=$ number of inverters; DMP = maximum power demand (W); PI = inverter power (W).

\subsubsection{General Remarks}

At first, the calculations for the design of On-grid and Off-grid wind systems, through direct or alternating current generators were the same, what effectively changed was the use of equipment for current conversion and when this need was identified, the application will return the required amount of these.

For the On-grid and Off-grid systems, the initial calculations regarding the energy demand to be supplied to the consumer were similar. However, in the On-grid system, the quantities and technical specifications of wind turbines and inverters are established according to the ANEEL resolutions 482/2012 and 687/2015. These resolutions, among other aspects, define the method of connection to the distribution network. On the other hand, Off-grid systems, in addition to the aforementioned equipment, load controllers and batteries, with their respective technical specifications, will also be sized.

It will be up to the system to verify all the necessary equipment for the project, either for isolated or connected to the network, besides the comparison between them presenting the best deployment situation to the user.

\section{Results and Discussion}

\subsection{DIMEE System}

The DIMEE (Computational System for Wind Scaling) was developed to assist in the designing and subsequent verification of the feasibility of a power generation project through the use of wind turbines, in an easy way and 
with the minimum of possible interactions between the computational system and its user. This tool provides a perspective of the necessary equipment for the deployment of a wind power system and its feasibility. In order to do this, it will suffice to insert the data requested in the simulation screen.

The DIMEE was divided into two main parts, the first one consists of the simulation environment, where the user informs the data needed to perform the simulation, and the second consists of the administration area, where the user performs the registration and editing of the necessary equipment for the deployment of a wind power system. These can be seen in Figure 1.
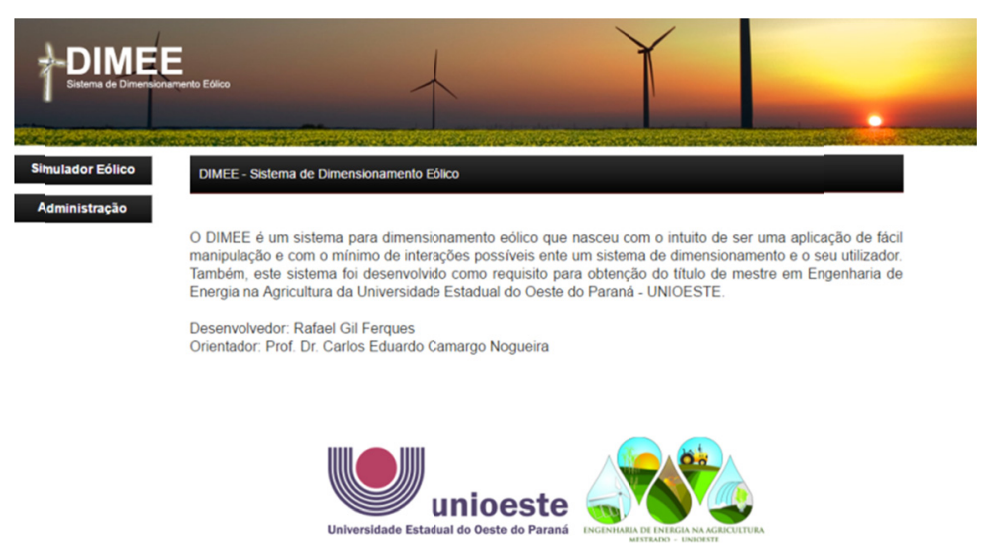

Figure 1. Main screen of DIMEE system

\subsection{Simulation}

After selecting the Wind Simulator option, the screen will appear to start the simulation, as shown in Figure 2.

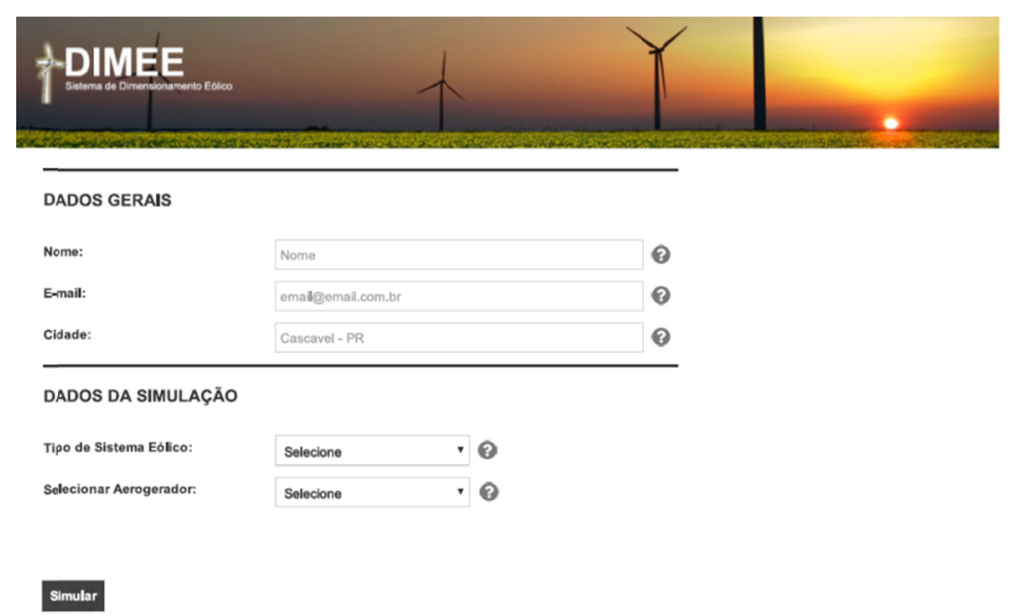

Figure 2. Start screen of the DIMEE system simulation

In this screen the user will enter the initial information as presented in the fields delimited in General Data (Name, E-mail, City), and in the sequence it will inform you what type of wind system will be used in the simulation, with On-Grid and Off-Grid options. The user will also be informed whether or not wish to attach a previously registered wind turbine model to follow the simulation. If it chooses not to select a wind turbine, the system will present, at the end of the simulation, which one is the most feasible, both in cost and in performance, for deployment. 
When selecting the first option (On-Grid) the other information required to follow the simulation (Electrical Data, Wind Data and Financial Data) is displayed as shown in Figure 3.
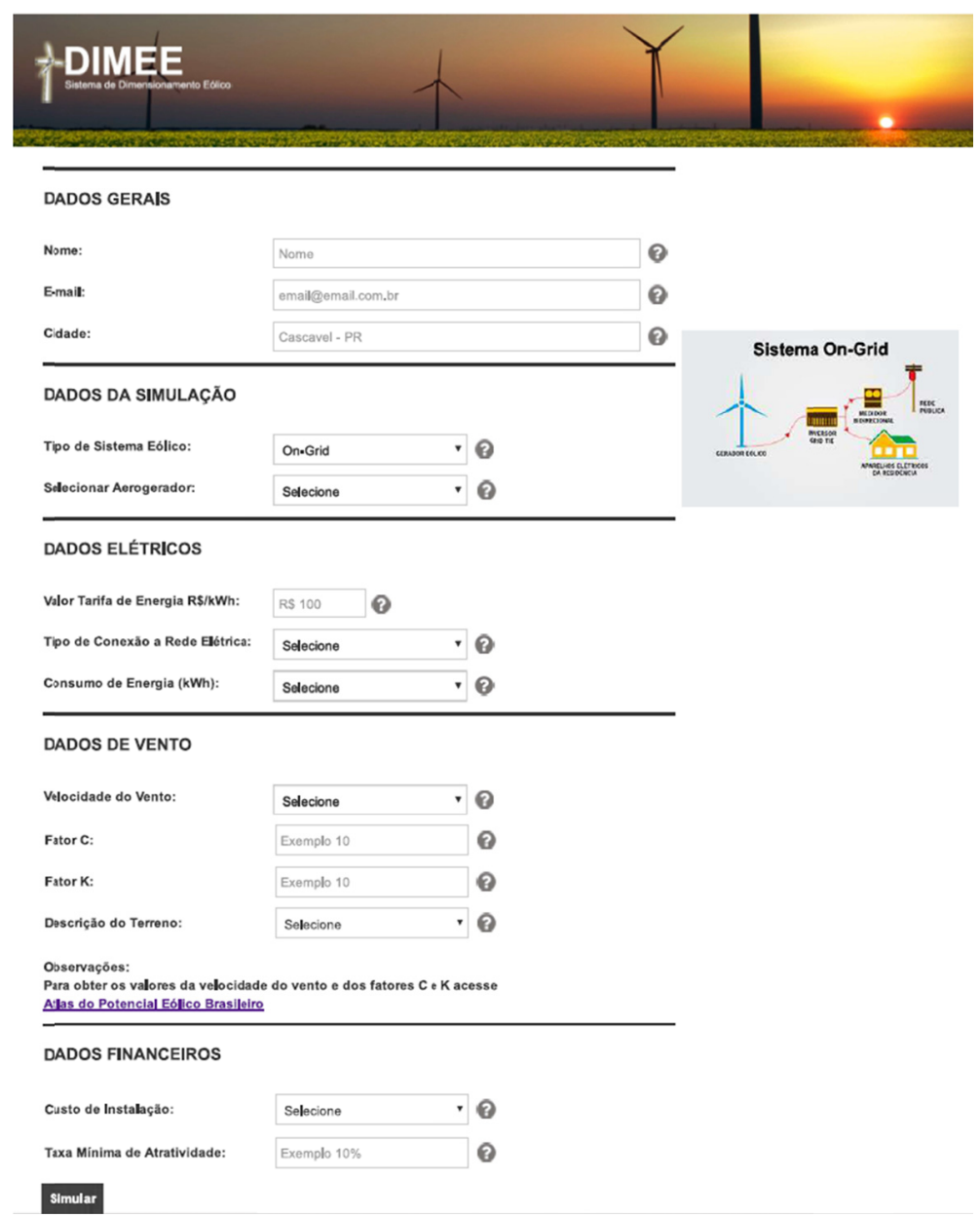

Figure 3. On-Grid system simulation screen

When selecting the second option in the Off-Grid field, the following information is displayed in addition to the input fields in the first option: Maximum Building Demand in kWh, Days of Autonomy and Depth of Battery Discharge. The availability of these requests is shown in Figure 4.

As shown in Figure 3, after selecting the type of Wind System to be simulated, when selecting the first option, the following is a field for insertion of the fares charged by the utility and the field of selection of the Type of Connection to the Electrical Network, which includes the options of single-phase, two-phase and three-phase systems. This scheme of insertion and options are visualized in Figure 5. 

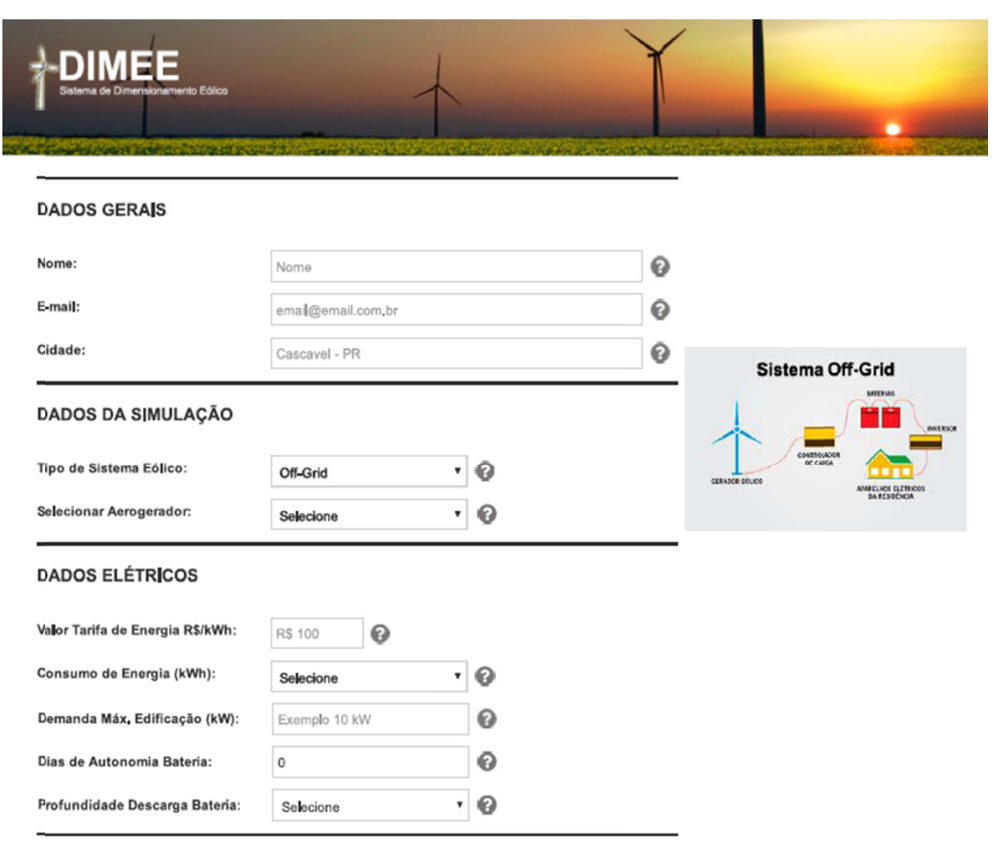

DADOS DE VENTO

Velocidade do Vento:

Fator C:

Fator K:

Descriçăo do Terreno:

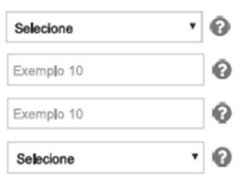

Observaçóes:
Para obter os valores da velocidade do vento e dos fatores $C$ e $K$ acesse

ellas do Potencial Édice Brasibite

DADOS FINANCEIROS

Custo de Instalaçăo:

Taxa Minima de Atratividade:

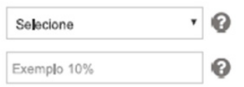

Simular

Figure 4. Off-Grid system simulation screen

In sequence, the user will enter information about their electrical consumption. There are two options for entering the information about electric consumption, one delimited "Manual", in which the information of the history of consumption of electric energy in $\mathrm{kWh} /$ month is inserted, and the other, called Electrical Simulator.

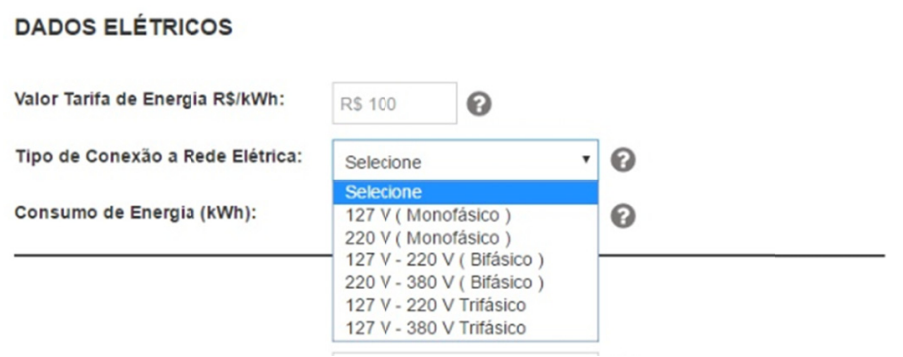

Figure 5. Electrical data screen-types of electrical connection

When you select the Manual option, a new screen is opened in which the user will enter the information, month by month, of the history of his electric consumption. When selecting the Electric Simulator option, as shown in Fig. 6, a new screen is opened which the user will select the equipment, inform the quantity, power in Watts and the time of use in hours per day, week or month of each one of the equipment inserted in the board. These 
equipment are previously registered and just like all other equipment used in the simulation are subject to insertion and editing.

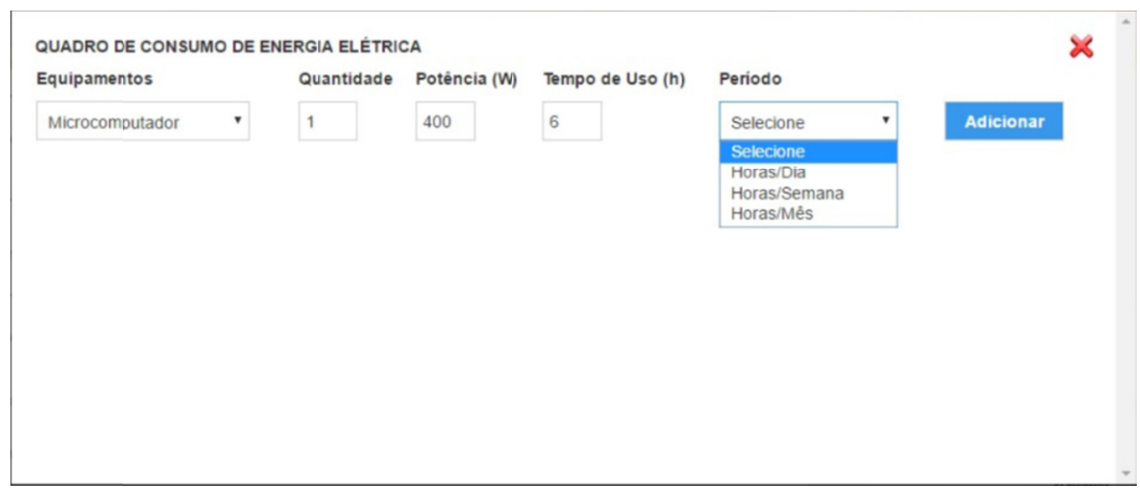

Figure 6. Electric simulator screen

After defining the reference values of the electrical data, the wind data are requested, these being: the wind speed, the values of Factors $\mathrm{C}$ and $\mathrm{K}$ of the Weibull probability density function and the description of the terrain where the wind system is to be installed. For wind speed data, Factors $\mathrm{C}$ and $\mathrm{K}$, there is an instruction on how to get them. For the insertion of the wind speed, the system offers two options called Temporal Series and Annual Average (Figure 7). When selected the Temporal Series option, a new screen will open where the user can inform how much wind speed data is wanted.

When selected the Annual Average option, a value input box is released, in which the user will inform the average wind speed in $\mathrm{m} / \mathrm{s}$. This information and the information of Factors $\mathrm{C}$ and $\mathrm{K}$, as informed previously, are made available through the Brazilian Wind Potential Atlas of CRESESB.

After insertion of the values described above there is the Land Description field, where the user will select the option that best corresponds to the location where the wind generator is to be installed, with the following options: No Vegetation, Lawn, Cultivated, With Few Trees, Many Trees, Close To Living, Not many Buildings, Forest, and Urban Zone.

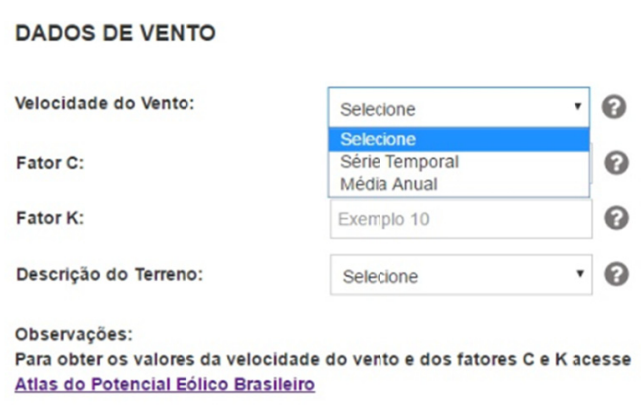

Figure 7. Wind data display—Wind speed option

The next step in the simulation is the insertion of financial data. In this part of the system the user will inform the value referring to the installation cost, in currency value or in percentage of the total value of the project, and the minimum rate of attractiveness in percentage. In relation to the installation cost, after selecting the input form of the reference value, a field will be released for insertion of this value which, as already described, may be a percentage of the total cost of the project or a fixed amount in the currency.

All previous descriptions refers to the simulation of an On-Grid system. For the simulation of an Off-Grid system the field Connection Type in Electrical Data, as shown in Figure 5, is not available and three new fields 
are available for insertion of values and thus enable the Off-Grid simulation, and they are: Maximum Building Demand, Days of Battery Runtime, and Depth of Battery Discharge. This scheme is shown in Figure 8.

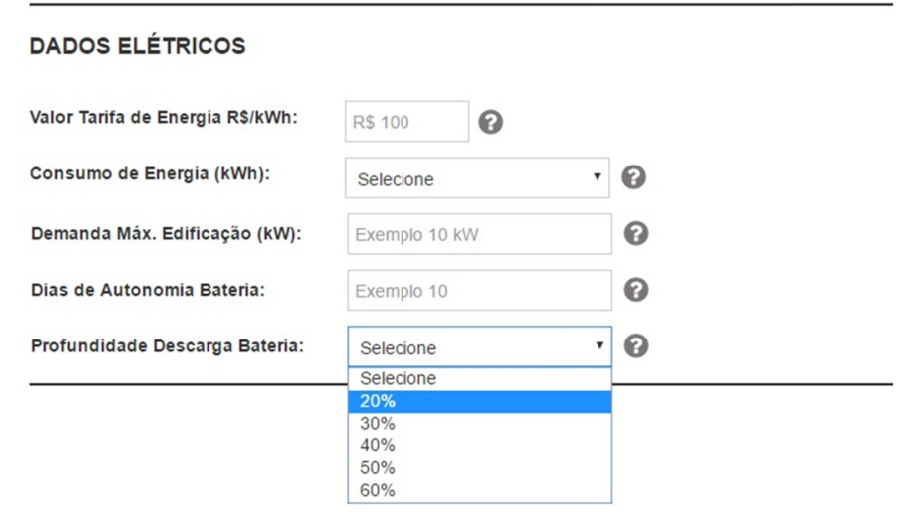

Figure 8. Screen electrical data-Simulation Off-Grid System

\subsection{Administration}

As informed, the system has two main parts, one of simulation and the second of administration, in which the user will be able, among other activities, to register and edit the necessary equipment for the implementation of a wind system. After selecting the Administration option, as shown in Figure 2, the Login screen will appear, where the user will enter the data to access this area. This access screen is shown in Figure 9.

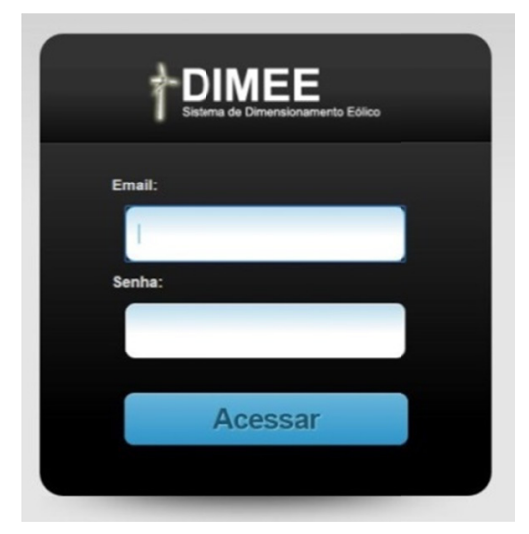

Figure 9. Admin login screen

After entering in the administration area, the user will have access to the control panel and later to the registers of all the equipment and to the content manager. The menus displayed in this control panel are: Wind Turbines, Batteries, Inverters, Load Controllers, Voltage Equipment, Electrical Equipment and Contents. This is shown in Fig. 10. When selecting the Wind Turbines menu, the user will have the options of visualization of the registered wind turbines and their respective information and the option of adding a new wind turbine to the library, as shown in Figure 10. 


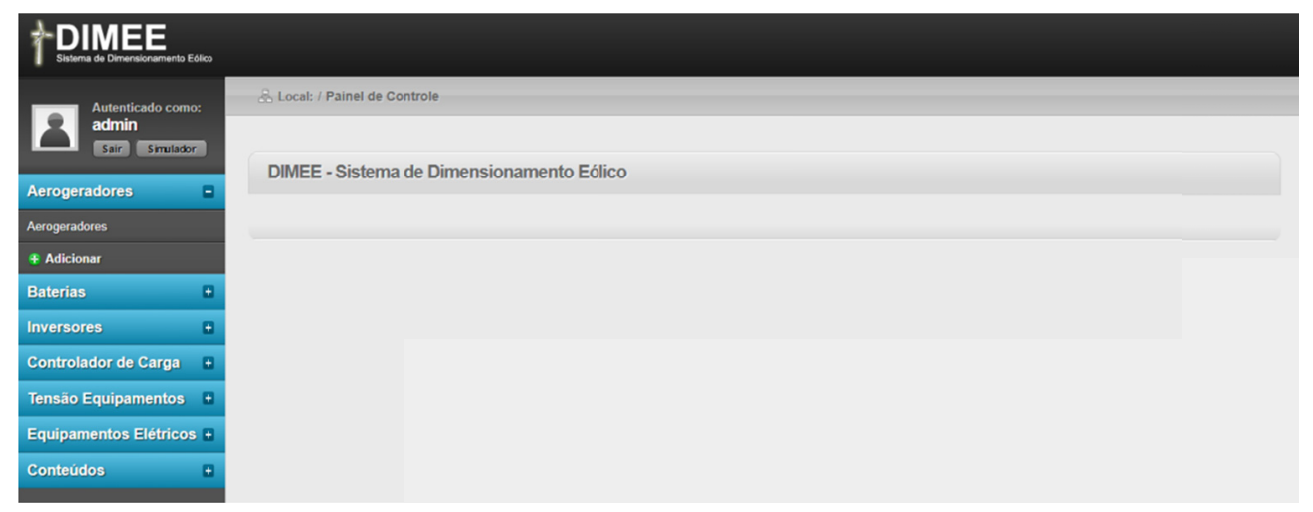

Figure 10. Control panel display—Wind turbines

When selecting the sub-menu Wind turbines is presented on the screen a listing containing the basic information of the registered wind turbines (Brand, Model and Price). In the same screen there is still the association of actions to each of the registered equipment being: Edit, in which you can make the changes in the register of the equipment registered; Delete, in which the exclusion of the register can be done; Power Curve, in which the power generation curve is presented and; Active/Inactive, in which it is possible to leave temporarily disabled or to rehabilitate for searches in the simulation the desired equipment. This scheme of options is seen in Figure 11.

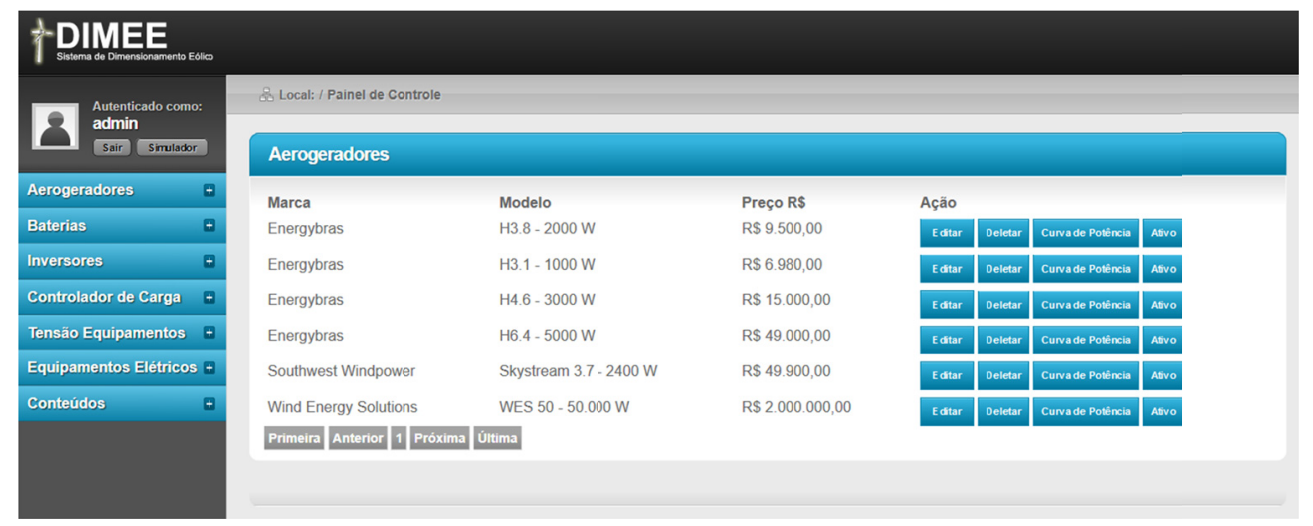

Figure 11. Wind turbines screen—Listing

When selecting the option Power Curve the user will be directed to a new screen, in which the graph of the respective curve is presented as a function of the wind speed in meters per second, as shown in Figure 12. These data are obtained by registering of speeds and powers in the insertion of a new wind turbine. 


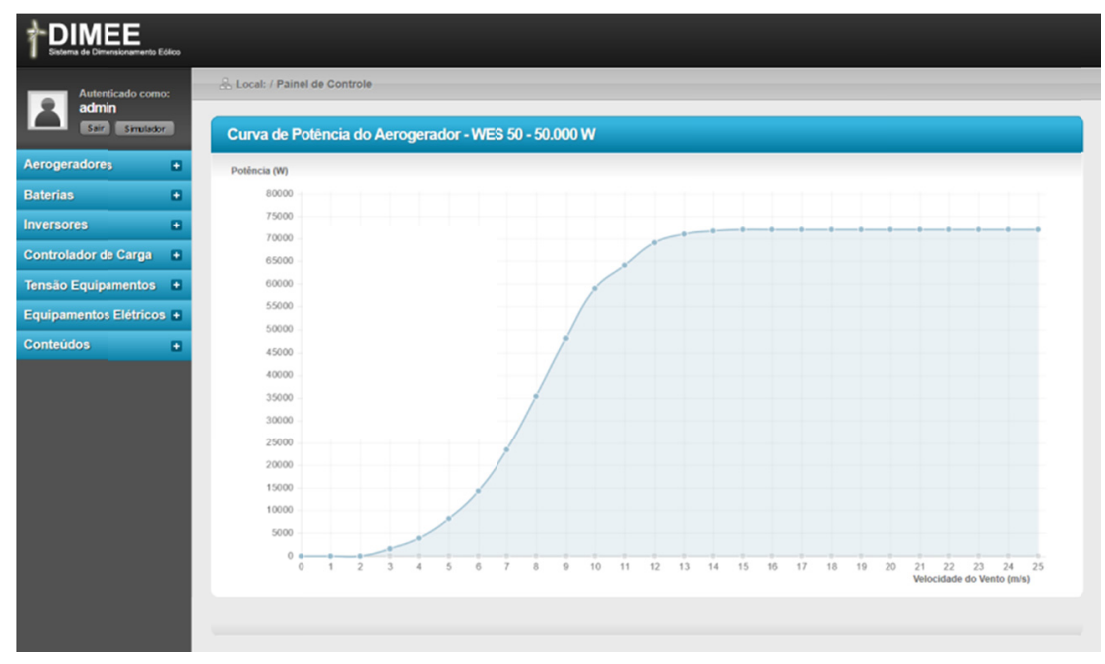

Figure 12. Wind turbine screen—Graph of the energy generation curve

By selecting the Add option in the Wind Turbines menu the user is directed to a new page in which it will enter the information to carry out a new registration. In this screen it will inform the Brand and Model of the wind turbine, it will inform if there is an Inverter Included and also if this Inverter is of the Type Grie Tie, it will inform the type of System of the Wind turbine, having the options of fixed speed and variable speed.

Following is the Inverter Rated Power fields in Watts, if there is an inverter included, Starting Wind Speed in meters per second, Useful Life in Years of the equipment and Price in currency.

In addition to the described options, the user can inform if the manufacturer makes available to the same model of wind turbine other configurations of Output Voltage, both for direct current $(12 \mathrm{~V}, 24 \mathrm{~V}, 36 \mathrm{~V}$ or $48 \mathrm{~V})$ and alternating current (Single Phase 127V and Single Phase 220V, Biphasic 127-22V and Biphasic 220V-380V or Three-phase $127 \mathrm{~V}-220 \mathrm{~V}$ and Three-phase $220 \mathrm{~V}-380 \mathrm{~V}$ ). For each of the output voltage options there is the possibility of inserting the additional value, if any, for each of these selected configurations.

Upon registration, the user will inform the Tower Height in Meters and Wind Tower Material. There is also a field for inserting General Notes, in which is possible to insert more information, if the user decides it is also important beyond the delimited ones in the system. Finally, there is the field for insertion of the power values generated by the wind turbine as a function of the wind speed in meters per second, called Data for Construction of the Power Curve. It will be up to the user to validate and verify the information entered in the system. Because it is a Web system, all those who use the system will have access to the same data available. All this information is shown in Figure 13. 


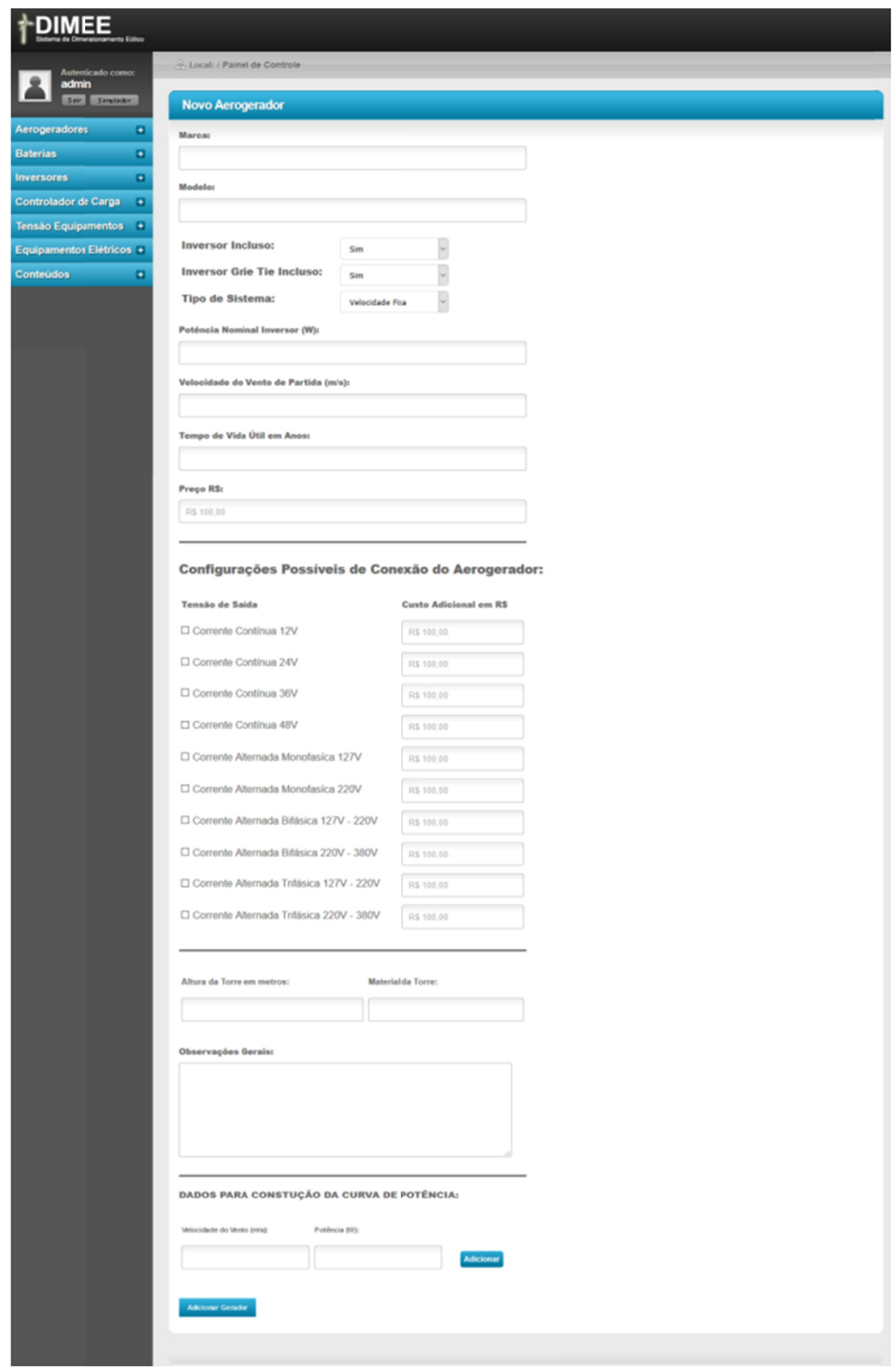

Figure 13. Wind turbine screen-New wind turbine registration

When selecting the Batteries menu, the user will have the options of displaying the batteries and their respective information and the option to add a new register. By selecting the Batteries submenu, a list containing the basic information of the registered batteries (Brand, Model, Voltage and Price) is displayed. In the same screen there is still the association of actions to each of the registered equipment being: Edit, in which changes can be made in the register of the equipment registered; Delete, in which it can be done to delete the register and; Active/Inactive, in which it is possible to leave temporarily disabled or to rehabilitate for searches in the simulation the desired equipment.

When you select the Add option in the Batteries menu the user is directed to a new window in which he will enter the information to carry out a new registration. In this screen it will inform the Brand and Model of the battery, also will select the Nominal Voltage in Volts, the nominal capacities for discharges in regimes of 10, 20 and 100 hours (Capacity C10, Capacity C20 and Capacity C100) and number of charge cycles and discharge for each of these settings. 
Following, is the Price and General Notes field, where you can enter other information which you think are important beyond the delimited ones in the system. When selecting the Inverters menu, the user will have the options of visualization of the registered inverters and their respective information and the option to add a new register.

When selecting the Inverters sub-menu, a list containing the basic information of the registered equipment (Brand, Model, Current Input Voltage, Alternating Current Output Voltage, Nominal Power in Watts and Price) is displayed. In the same screen there is also the association of actions to each of the registered equipment being: Edit, in which changes can be made in the register of the equipment registered; Delete, in which it can be done to delete the register and; Active/Inactive, in which it is possible to leave temporarily disabled or to rehabilitate for searches in the simulation the desired equipment.

When you select the Add option in the Inverters menu the user is sent to a new page where he will enter the information for the new register. In this screen, the Brand and Model of the inverter are requested, the Rated Power in Watts, the Inverter Efficiency in percentage and the Watt Power in Watts. It will also select the Input Voltage in Volts, if this inverter is of the Grie Tie Type and Inverter Wave Type with the options: Pure Senoride, Modified Senoid or Square Wave. You can then enter the value of the Output Voltage for Alternating Current, the value of the Input Current and the Output Current in Amps in addition to the Lifetime Field in Years field. There are still the fields Price and General Remarks, where you can enter other information which you think are important beyond the delimited ones in the system.

When selecting the Load Controller menu, the user will have the options of visualising the registered load controllers and their respective information and the option of adding a new equipment to the register. When selecting the Load Controller sub-menu, a list containing the basic information of the registered equipment (Brand, Model, Load Capacity, Voltage and Price) is displayed. In the same screen there is still the association of actions to each of the registered equipment being: Edit, in which changes can be made in the register of the equipment registered; Delete, in which it can be done to delete the register and; Active/Inactive, in which it is possible to temporarily disable or re-enable the desired equipment to be searched for in simulation, as shown in Figure 14. When you select the Add option in the Load Controller menu, the user is taken to a new page where he will enter the information for a new registration. In this screen is requested the Brand and Model of the load controller, the Current Capacity in Amps. It is still necessary to select the Input Voltage in Volts and the Output Voltage in Volts, in addition to the Years of Useful Life Time field, Price in currency and General Remarks, where it is possible to enter other information which the user judges necessary beyond the delimited in the system.

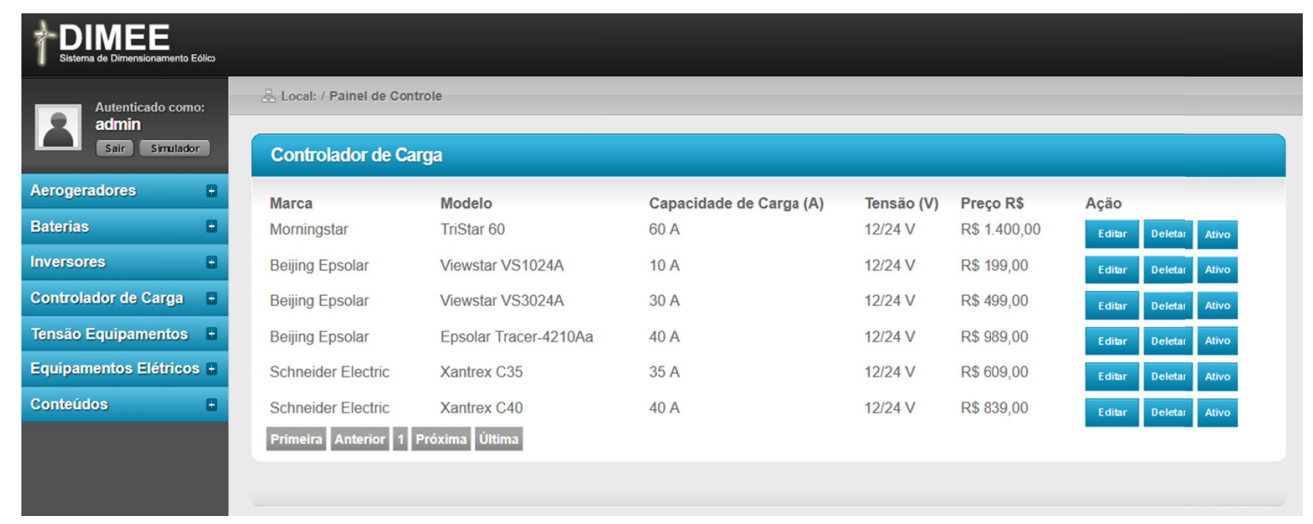

Figure 14. Load controller screen—Listing

When selecting the Equipment Voltage menu, the user will have the options of visualizing the voltages registered and their respective information and the option to add a new register. When selecting the Equipment Voltage submenu, a list containing the voltages entered is displayed. These values will be used in all previously submitted entries. In the same screen there is still the association of actions to each of the tensions registered, these are: Edit, in which you can make changes to the registered equipment register and Delete, in which the registration can be made. 
Selecting the Add option in the Voltage Equipment menu will bring the user to a new page where he will enter the information for a new registration. Voltage in Volts is requested on this screen.

When selecting the Electrical Equipment menu, the user will have the options of visualization of the equipment registered and its respective information and the option to add a new register. When selecting the Electric Equipment sub-menu, a list containing the registered equipment is displayed. These values will be used in the electric simulation table. In the same screen there is still the association of actions to each one of the registered tensions, being these: Edit, in which changes can be made in the register of the equipment registered and Delete and Active/Inactive, where it is possible to leave temporarily disabled or rehabilitate for in the simulation of electric consumption, in which the registration can be excluded.

Selecting the Add option in the Electrical Equipment menu, the user is taken to a new page where he will enter the information for a new registration. The name of the equipment is requested on this screen.

When you select the Content menu, the user will have the options for viewing and then editing the content displayed on the home screen. When requesting the edition, the user is referred to a new screen in which he will have a text editor and can perform the insertion or change of the initial information of the system. This field is used only for system presentation text.

\subsection{On-Grid Wind Simulation}

At the end of the simulation a report containing the simulation information and the results of the simulation is presented, as shown in Figure 15.





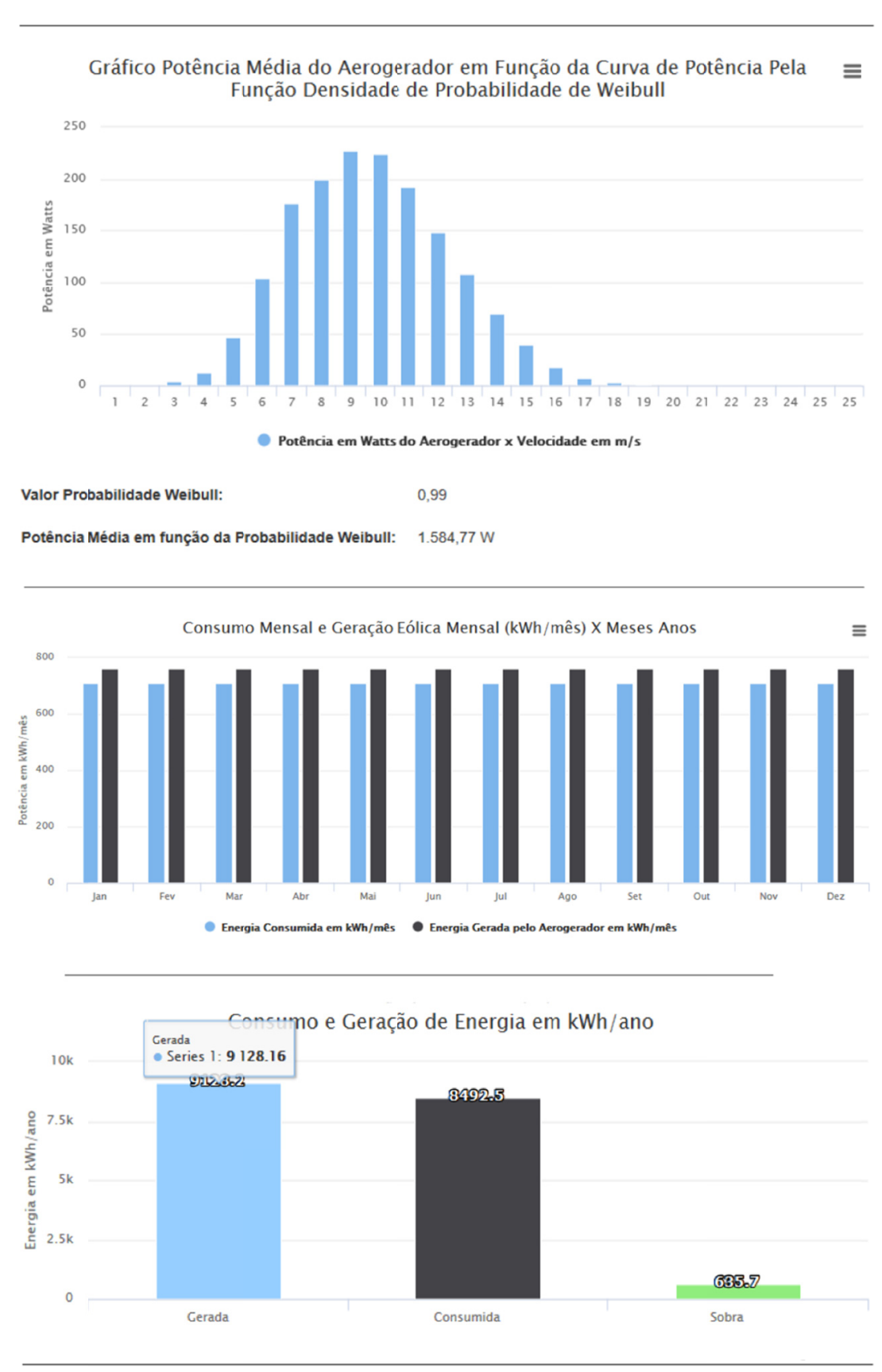

Distribuição dos Custos no Projeto

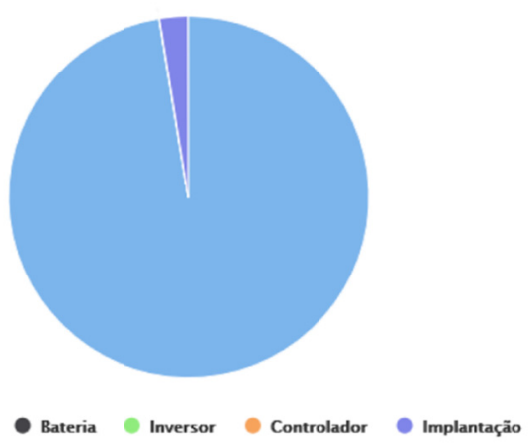




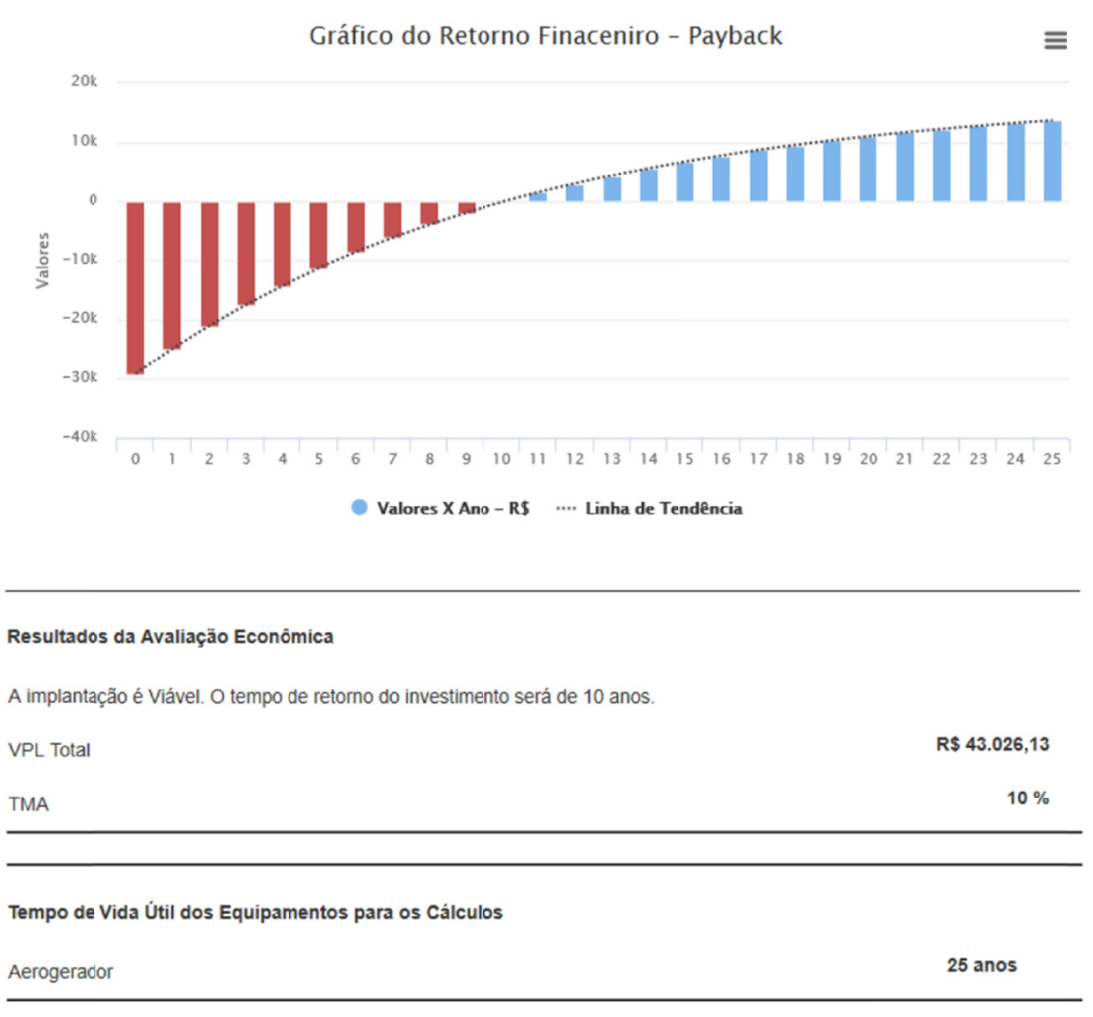

Figure 15. On-Grid simulation report

\subsection{Off-Grid Wind Simulations}

At the end of the simulation, a report containing the simulation information and the results of the simulation is presented, as shown in Figure 16.

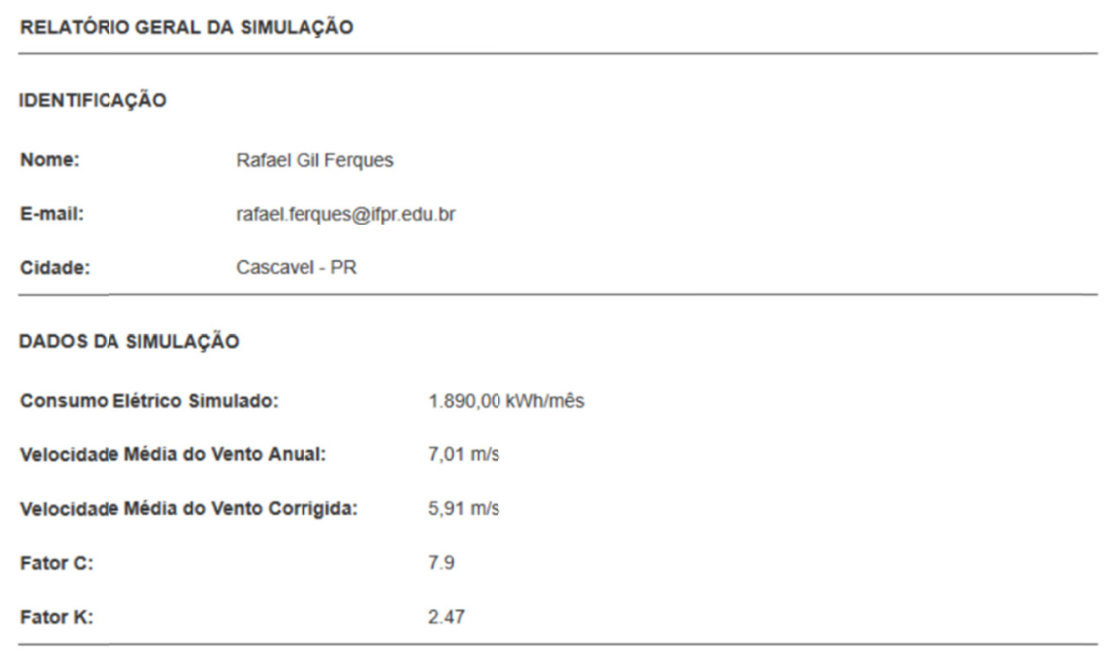


TABELA FINANCEIRA (FÍSICO/FINANCEIRO)

\begin{tabular}{|c|c|c|c|}
\hline Descriçäo & Quantidade & Custo Unitário & Custo Total \\
\hline Aerogerador Energybras - H3.8 - 2000 W & 7 & R\$ $9.500,00$ & $\mathrm{R} \$ 66.500,00$ \\
\hline Controlador de Carga Morningstar - TriStar 60 & 8 & R\$ $1.400,00$ & RS $8.400,00$ \\
\hline Bateria Moura - Clean 12MF220 & 68 & RS $1.099,00$ & R\$ $71.435,00$ \\
\hline Custo da Instalação & & & RS 750,00 \\
\hline TOTAL GERAL & & & R\$ $147.085,00$ \\
\hline
\end{tabular}

\section{OBSERVAÇÖES GERAIS}

Altura da Torre: 12 metros.

Material da Torre: Treliça.

Controlador de Carga com corrente máxima de 60A

Bateria estacionária de 220 Ah.

Controladores de carga conectados em paralelo.

Baterias conectadas em série de quatro baterias e o restante em paralelo.

Gráfico Potência Média do Aerogerador em Função da Curva de Potência Pela $\equiv$ Função Densidade de Probabilidade de Weibull

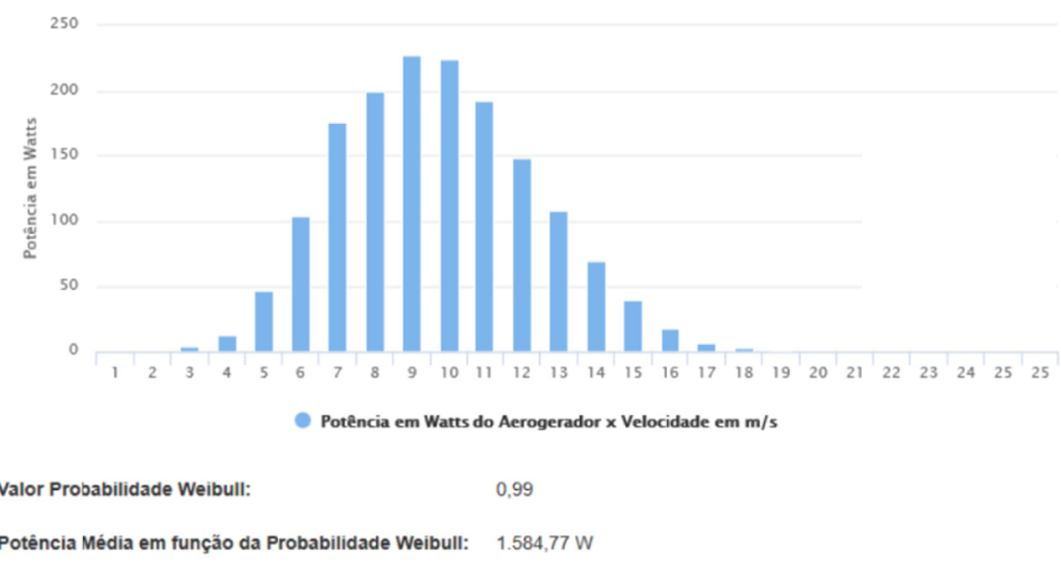

Distribuição dos Custos no Projeto

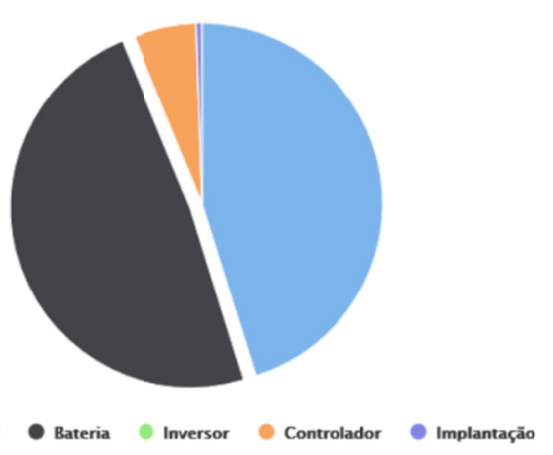




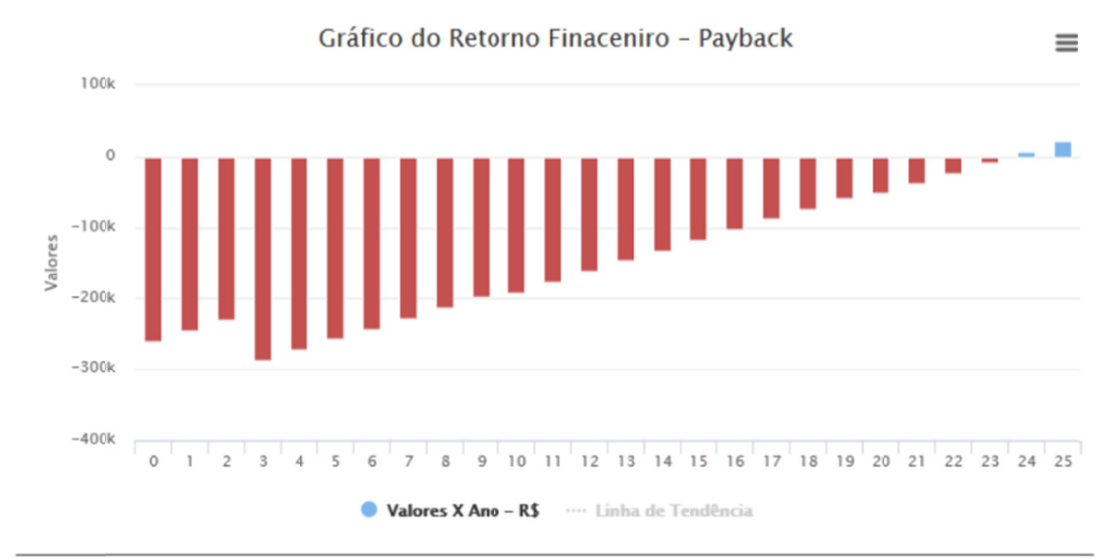

Resultados da Avaliação Econômica

A implantação é Viável. O tempo de retorno do investimento será de 24 anos

\begin{tabular}{lr} 
VPL Total & RS $133.813,72$ \\
TMA & $10 \%$ \\
\hline
\end{tabular}

Tempo de Vida Útil dos Equipamentos para os Cálculos

\begin{tabular}{lc} 
Aerogerador & 25 anos \\
Bateria & 3 anos \\
Inversor & 10 anos \\
Controlador de Carga & 10 anos \\
\hline
\end{tabular}

Figure 16. Off-Grid simulation report

\section{Conclusions}

The application has proven effective in sizing and economic analysis of small wind systems, allowing fast and simple simulation of On-Grid systems and Off-Grid systems. In addition, it proved effective in storing and accessing the information regarding the simulations performed and in the comparison between them, in order to perform a new simulation. Also, it was reliable in the accomplishment of the economic analysis, returning in a clear way the feasibility or not of the implantation of the project.

\section{References}

Ackermann, T. (2012). Wind power in power systems (2nd ed., p. 1020). England: Wiley. https://doi.org/10.1002/ 9781119941842

ANEEL (Agência Nacional de Energia Elétrica). (2008). Atlas da Energia Elétrica do Brasil (3rd ed., p. 236). Brasília.

ANEEL (Agência Nacional de Energia Elétrica). (2016). Retrieved from http://www.aneel.gov.br/informacoestecnicas

Albano, J. M. M. (2009). Estudo comparativo entre sistema de produção clássico e sistema com energias alternativas (p. 112, Dissertação (Mestrado em Engenharia Eletrotécnica e de Computadores), Universidade Técnica de Lisboa, Lisboa).

Anders, U., \& Korn, O. (1999). Model selection in neural networks. Neural Networks Journal, 12(2), 309-323. https://doi.org/10.1016/S0893-6080(98)00117-8

Associação Brasileira de Energia Eólica Disponível. (2016). Retrieved from http://www.portalabeeolica.org.br

Blasques, L. C. M. (2005). Estudo da viabilidade técnico-econômica de sistemas híbridos para geração de eletricidade (p. 215, Dissertação (Mestrado em Engenharia Elétrica), Universidade Federal do Pará, Belém). 
CRESESB (Centro de Referência para Energia Solar e Eólica Sérgio de Salvo Brito). (2014). Manual de Engenharia para Sistemas Fotovoltaicos (p. 215).

Dawson, C. W., \& Wilby, R. (1998). An artificial neural network approach to rainfall runoff modelling. Hydrological Science Journal, 43(1), 47-66. https://doi.org/10.1080/02626669809492102

Dutra, R. M., \& Tolmasquim, M. T. (2002). Estudo da viabilidade econômica para projetos eólicos com base no novo contexto do setor elétrico. Revista Brasileira de Energia, 9(1).

Gallant, S. L. (1995). Neural network learning and expert systems (3rd ed., p. 382). Massachusetts: The MIT Press.

GWEC (Global Wind Report). (2015). Retrieved June 26, 2016, from http:/www.gwec.net/wp-content/ uploads/vip/GWEC-Global-Wind-2015-Report_April-2016_22_04.pdf

Hamzaçebi, C. (2008). Improving artificial neural networks performance in seasonal time series forecasting. Information Sciences an International Journal, 178(23), 4550-4559. https://doi.org/10.1016/j.ins.2008. 07.024

Haykin, S. (2000). Redes neurais princípios e prática (2nd ed., p. 900). Porto Alegre: Bookman.

Heaton, J. (2008). Introduction to neural networks with Java. (2nd ed., p. 477). St. Louis: Heaton Research Inc.

Hoji, M. (2014). Administração Financeira e Orçamentária (11th ed., p. 608). São Paulo: Atlas.

JangamshettI, S. H., \& Rau, V. G. (2009). Site matching of wind turbine generators: A case study. IEEE Transactions on Energy Conversion, 14(4), 1537-1543. https://doi.org/10.1109/60.815102

Ljung, L. (2016). System identification toolbox user's guide R2016a (p. 1086). Natick: The Math Works, Inc.

Lopes, L. F. da R. (2011). Importância da energia renovável para o meio ambiente (p. 384, Monografia (Especialização em Gestão Ambiental), Universidade Candido Mendes, Rio de Janeiro).

Luzio, E. (2014). Finanças corporativas teoria e prática (2nd ed., p. 384). Rio de Janeiro: Senac Rio.

Martins, F. R., Guarnieri, R. A., \& Pereira, E. B. O. (2008). Aproveitamento da energia eólica. Revista Brasileira de Ensino de Física, 30(1). https://doi.org/10.1590/S0102-47442008000100005

Melek, V. C. (2013). Estudo comparativo da viabilidade econômica entre uma usina eólica e uma usina híbrida (eólico-fotovoltaica) (p. 86, Trabalho de conclusão de curso (Especialização em Eficiência Energética), Universidade Tecnológica Federal de Paraná, Curitiba).

Melo, E., Santos, R., \& Yamamoto, S. (2016). As políticas energéticas e a regulamentação do marco legal do mercado brasileiro de energia renovável. Retrieved from http://abeeolica.org.br/pdf/Artigo-ForumNacional-Opcao-pela-Energia-hidroeletrica-e-outras-energias-renovaveis.pdf

Minns, A. W., \& Hall, M. J. (1996). Artificial neural networks as rainfall-runoff models. Hydrological Sciences Journal, 41(3), 399-417. https://doi.org/10.1080/02626669609491511

Newnan, D., Eschenbach, T., \& Lavelle, J. (2013). Engineeniring Economics Analysis (12th ed., p. 704). Oxford: Oxford University Press.

Nguyen, K. Q. (2007). Alternatives to grid extension for rural electrification: Decentralized renewable energy technologies in Vietnam. Energy Policy, 35(4), 2579-2589. https://doi.org/10.1016/j.enpol.2006.10.004

Nogueira, C. E. C. (2004). Dimensionamento de sistemas integrados de energia em ambientes rurais (p. 134, Tese de Doutorado (Engenharia Elétrica), Universidade Federal de Santa Catarina, Florianópolis).

Pinho, J. T., Barbosa, C. F. O., Pereira, E. J. da S., Souza, H. M. S., Blasques, L. C. M., \& Galhardo, M. A. B., \& Macêdo, W. N. (2008). Sistemas híbridos-Soluções energéticas para a Amazônia (p. 398). Brasília: Ministério de Minas e Energia.

Pinto, M. O. (2013). Fundamentos de energia eólica (p. 368). Rio de Janeiro: LTC.

Pressman, R. S. (2014). Software engineering a practitioner's approach (8th ed., p. 976). New York: McGraw Hill.

Rebelatto, D. (2004). Projeto de Investimento (p. 329). São Paulo: Manole.

REN21. (2016). Renewables 2011 Global Status Report. Renewable Energy Policy Network for the 21st Century, 2011. Retrieved from http://www.ren21.net/Portals/97/documents/ 
Riad, S., Mania, J., Bouchaou, L., \& Najjar, Y. (2004). Rainfall-runoff model using an artificial neural network approach. Mathematical and Computer Modelling, 40(7), 839-846. https://doi.org/10.1016/j.mcm. 2004.10.012

Sedki, A., Ouazar, D., \& El mazoudi, E. (2009). Evolving neural network using real coded genetic algorithm for daily rainfall runoff forecasting. Expert Systems With Applications, 36(1), 4523-4527. https://doi.org/ 10.1016/j.eswa.2008.05.024

Shamseldin, A. Y. (1997). Application of a neural network technique to rainfall-runoff modelling. Journal of Hydrology, 199(3), 272-294. https://doi.org/10.1016/S0022-1694(96)03330-6

Sommerville, I. (2016). Software Engineering (10th ed., p. 816). Boston: Pearson Prentice Hall.

Thierens, D., \& Goldberg, D. E. (1994). Convergence models of genetic algorithm selection schemes. Proceedings of the International Conference on Evolutionary Computation (pp. 119-129). The Third Conference on Parallel Problem Solvingfrom Nature. https://doi.org/10.1007/3-540-58484-6_256

Tourkolias, C., \& Mirasgedis, S. (2011). Quantification and monetization of employment benefits associated with renewable energy technologies in Greece. Renewable and Sustainable Energy Reviews, 15(6), 2876-2886. https://doi.org/10.1016/j.rser.2011.02.027

Wang, W., Chau, K., Cheng, C., \& Qiu, L. (2009). A comparison of performance of several artificial intelligence methods for forecasting monthly discharge time series. Journal of Hydrology, 374(3), 294-306. https://doi.org/10.1016/j.jhydrol.2009.06.019

Willis, H. L., \& Scott, W. G. (2000). Distributed Power Generation Planning and Evaluation (p. 616). New York: Marcel Dekker, Inc.

\section{Notes}

Note 1. http://www.wwindea.org

Note 2. http://www.gnu.org/licenses/licenses.html\#GPL

Note 3. Available: http://code.google.com/p/matlabcontrol

Note 4. http://www.cresesb.cepel.br/index.php?section=atlas_eolico

\section{Copyrights}

Copyright for this article is retained by the author(s), with first publication rights granted to the journal.

This is an open-access article distributed under the terms and conditions of the Creative Commons Attribution license (http://creativecommons.org/licenses/by/4.0/). 